\title{
The Impact of Village Policies in Handling Covid-19 on the Community Economy
}

\author{
Cecep Nugroho \\ \{cecepnugroh@gmail.com\} \\ Case in Sindangjaya Village, Brebes
}

\begin{abstract}
The policy of limiting community activities caused by the Covid-19 pandemic is not only at the national, provincial, and district levels, but also at the village level. As a result of these restrictions, farmers and pitchmen who are the livelihoods of the people of Sindangjaya, have suffered losses. By using qualitative research with an ethnographic type, this research reveals 1) What are the policies of Sindangjaya Village in responding to the Covid-19 pandemic; 2) What is the impact of the policy on the community's economy. The results showed that the farmers' economy declined due to limited activities so that the plantations were not well maintained which caused the yields to be less than optimal and farmers had difficulty selling their harvests which required sending them to big cities due to this restriction. On the other hand, pitchmen are confused about selling their products. However, the village government does not stay silent and looks for solutions to overcome this problem such as making processed products from the harvest into various types of food and the village government recommends selling the food using social media, but because the majority of pitchmen are elderly and not all have smartphones, it takes time. long enough to get over it. The existence of an impact that is directly felt by the village community shows that there is a direct relationship between policies and people's lives
\end{abstract}

Keywords: Policy; Village; Pandemic; Economic Loss

\section{Introduction}

The Coronavirus, also known as COVID-19, was first detected in the city of Wuhan, China. COVID-19 is an infectious disease caused by severe acute respiratory syndrome coronavirus 2 or SARS-CoV-2. This virus is a type of coronavirus that can infect animals. When infecting humans, Coronaviruses usually cause infectious diseases of the respiratory tract, such as the flu, MERS (Middle East Respiratory Syndrome), and SARS (Severe Acute Respiratory Syndrome) (Setiawan, 2020). This virus is very dangerous because it attacks parts of the human respiratory tract to cause several effects from the most common such as fever and cough to difficulty breathing or shortness of breath, even the most serious symptoms of loss of ability to speak and move, therefore people are prohibited from gathering in public places. 
David Easton defines public policy as the forcible allocation of values to all members of society (Easton, 2013). The purpose of public policy is to obtain values by the public, both related to public goods and public services. These values are needed by the public to improve the quality of life, both physical and non-physical. There are several important characteristics of the policy: 1). The policy is a government action that aims to create public welfare. 2). Policies are made through systematic stages so that all the main variables of all the problems to be solved are included. 3). The policy must be implemented by the implementing organizational unit. 4). Policies need to be evaluated so that it is known whether they are successful or not in solving problems (Dye, 1984).

According to Sukirno, economics is a study of individuals and society making choices, with or without the use of money, by using limited but usable resources in all ways to produce various types of goods and services and distribute them for consumption needs, now and of course in the future. future, to individuals and groups of society (Sukirno, 2013). So it can be said that the economy is an important thing in human life. Economics is one of the activities carried out by humans to obtain better survival, starting from producing, distributing, and consuming (Abdullah, 2011). While the rural economy is a community activity in developing the economic system in the village. The village is a legal community that has jurisdictional boundaries, authorized to regulate and manage the interests of the local community. The rural economic system will always face problems in the economy itself, this problem aims to be able to get prosperity (Adji, 2004).

In a study conducted by Susilawati and Razi on the Policy of the Lowayu Village Government, Dukun Subdistrict, Gresik Regency in Economic Reconstruction after the COVID-19 Pandemic. According to Diyan and Fahrur in their research on policies in Lowayu village as an effort to improve and restore people's lives, there were several policies issued including restrictions on population movement such as the closure of the Turi Lowayu Market where only the Lowayu community were allowed to operate in the market with strict procedures. As well as for shop owners to provide tools such as handwashing stations and of course they must comply with health protocols. Therefore, restrictions on outside traders or shippers from supplying shops are restricted until the new normal transition period with strict protocols in order to maintain the comfort and concern of residents (Susilawati \& Razi, 2020).

The ethnographic approach was used which was the most suitable approach because it directly interviewed the interviewees and talked face to face so that they could get quite accurate information because they were directly from those who experienced or were affected by the village government's policies. The population in this study is the community in Sindangjaya Village, Ketanggungan, Brebes, Central Java. In this research, the researcher used the purposive sampling technique. The criteria in this study were the Sindangjaya village community who were cooperative and willing to become participants. Participants in this study amounted to 4 people who have different backgrounds. The data collection process was carried out on 10-30 May 2020.

The instruments in this study used interview guidelines, observation sheets, recording during interviews, as well as books and stationery that helped the data collection process take place. The list of questions used as a guideline for interviews is as follows: (1) How does the village government take steps to determine policies towards its community. (2) What is the Impact of Village Government Policies on the Education Sector. (3) What is the Impact of Village Government Policies on the Economic Sector. 


\section{Findings}

After the researchers conducted research in the village of Sindangjaya, Ketanggungan, Brebes, Central Java. Researchers have successfully interviewed 4 sources with initials, namely $\mathrm{AB}, \mathrm{CR}, \mathrm{OB}, \mathrm{AK}$. With the original language, namely Sundanese and also provided which has been translated into Indonesian. Interviews with resource persons with the initials AB were held on Thursday, May 14, 2020; resource persons with the initials CR were held on Sunday, 17 May 2020; while the resource persons with the initials OB and AK were held on Tuesday, May 12, 2020.

Data that were not revealed through interviews, were supplemented with data from direct participatory observations conducted between 10-30 May 2020. To strengthen the substance of the data from interviews and observations, a search was carried out on existing documents and archives. All data from this research are described based on the focus of the research questions as follows:

a) How the Village Government Takes Steps to Determine Policies for Its Community

As a village apparatus in determining a policy to be issued, they must think about the community first so that there are no unnecessary mistakes. Researchers interviewed $\mathrm{AB}$ as village officer.

Sundanese / Native Language

"strategi nu ampuh jang nentuken kebijakan mah da kudu na survei hela ka masyarakat amih nyaho naon bae keluhan ataua permasalahan na nu dirasaken ku masyarakat amih kebijakan eta teh te ngarugiken masyarakat, amih kebijakan na lancar ewh halangan ti masyarakat"

English

"A powerful strategy in determining policy is to conduct a survey of the community to find out what complaints or problems are felt by the community so that there are no policies that end up harming the community so that policies will run smoothly without any obstacles from the community itself."

So that in this interview it can be concluded that the village government is not arbitrary in determining a policy so that the community does not feel the difficulties or problems that harm them.

b) What is the Impact of Village Government Policies on the Education Sector

The researcher interviewed CR 8th grade junior high school students he complained about the less than optimal results from studying at home

Sundanese / Native Language

"Kumaha erk pinter ai diajar di sakolaan oge nu pajele jng guru na langsung sok laku hese kana paham komo dei ie atuh beki bingung sorangan, malah ai diimah oge English lewih remen maen game tidan belajar na."

"How do you want to be smart if you study in school face to face with the teacher still don't understand and I'm confused what to do, even when I'm at home I play games more than study."

From the statement he made, it can be concluded that studying at home for him is less effective.

c) What is the Impact of Village Government Policies on the Economy 
In the face of this pandemic, surely some residents will face a crisis that is very detrimental to all circles. According to $\mathrm{O}$ as an onion farmer in Sindangjaya village.

Sundanese / Native Language

"Abdi sebagai petani ngarasaken dampak na, ai bawang panen kami para petani bingung kudu ngajual kani da kota gs te mungkin da PSBB tuluyna daek te daek nya English di garingken jang binih musim nu erk amih te rugi teing".

"I was a small farmer really feel the impact, when we harvest onions the farmers are confused about where to sell because it is not possible to go to the city with the PSBB system so like it or not we store onions by drying for seeds for the next season so as not to lose because there is no income" (Okian, 2020)

Meanwhile, according to sources, $\mathrm{AK}$ as a pitchman also complained about the same thing. Sundanese/Native Language

"Cek abdimah kebijakan pemerintah desa nggs hade da nentuken kebujakan nang nyele tina keadaan masyarakat ongkoh ti sakabeh kalangan. Aning aing pribadi gs sakumaha poe bae ewh pemasukan jeng malah mah rugi da te bisa jualan. Aing erk meli barang jang jualan di pasar gs ewh da di lockdown, aing laku bingung kudu kumaha dei ie."

English

"I think the village government's policy is good enough because it determines a policy by looking at the condition of the community from various circles. But I personally have had no income for several days and even I experienced losses because I could not sell. I want to buy goods to sell in the market now that the market has been locked down, I am very confused and don't know what to do if this goes on any longer."

Based on the results of interviews conducted by researchers, it was concluded that the problem in this field is the absence of a shopping center which is usually a field for rupiah coffers to sustain their lives.

\section{Results and Discussion}

After conducting research using the method of interviews and observations that researchers did. So it has been found some desired or needed data either from interviews or observations, the researchers will analyze existing findings and modify existing theories then build new theories and explain the implications of the results of research on Sindangjaya village government policies regarding COVID-19 On the Community Economy.

As explained in the data analysis technique in the study, the researcher used descriptive qualitative analysis (exposure) and the data obtained by the researcher either through observation, interviews, and documentation from parties who knew about the data needed by the researcher. The data are as follows:

a) Contents of Sindangjaya Village Government Policy

After conducting interviews with one of the village officials who were involved in making village government policies, the researchers finally obtained data on what policies the Sindangjaya village government had regarding Covid-19. The contents of the village government policy are: 
1. The entire Sindangjaya community is prohibited from holding events that can bring crowds of people from inside or outside the village.

2. Limiting the activities of farmers and mobile traders in order to suppress movements that cause the spread of the virus.

3. It is forbidden to leave the village or enter (for people outside the village or homecomers) unless there is a very urgent interest and must go through the protocol that has been set by the village government.

4. It is forbidden to carry out the Nganjang and Takbir Roving traditions on Eid night.

From this policy, there is still leeway for activities carried out in the village because it is far from the city center and no one is affected or affected by COVID-19, only activities carried out with other villages are strictly prohibited so that there are no victims infected from other villages.

b) The Impact of Village Government Policies on the Community

In the policies issued, there are unavoidable impacts, but all of this is done for the good of the community because this policy it has been carefully formulated in order to minimize the impact that will occur if left alone.

1. Economic Impact. One of the unavoidable impacts is the economic impact because apart from the lack of sufficient income, there are also more and more expenditures considering that Eid is approaching. The harvest that had difficulty in the sales process became the main factor in this case, which should have been the only source of income, has now disappeared due to difficulties in accessing sales to the city area. Although many efforts have been made by the government to reduce losses during the pandemic, not to mention that before the pandemic hit, the economy was not completely evenly distributed so that this pandemic really worsened the situation in the village of Sindangjaya. Although there are some who rack their brains to sell using social media, not all of them can use social media because the majority are quite advanced and will experience difficulties due to facilities and technological stuttering.

2. Social Impact. Another impact, in this case, is the social impact, this happens in addition to worrying about the disease that continues to spread to every area that makes people panic, another factor is also the depleting economic situation due to the absence of income so that it becomes a burden on the community. In this case, the people of Sindangjaya village continue to feel pressured because every time there is a dead victim, it must be carried out according to the protocol that has been determined by the government even though the victim did not die due to COVID-19. This incident caused unrest for the residents because apart from being impressed by the media, they were scaring or exaggerating the news.

3. Political Impact. The impact that is no less important is the political impact, when this pandemic took place, it so happened that the village of Sindangjaya just inaugurated the village head a few months ago in August 2019, so the atmosphere was still not conducive and many took advantage of this moment to make the village government seem to be working badly and many opposition parties who vilify government policies so that the upheaval is heating up again about it. 


\section{Conclusion}

This article is intended to add knowledge and insight on how to make decisions when the situation is critical for the good of the people and to know the complaints of the community during the pandemic. Based on the results of the preparation of the Final Project, it can be concluded:

All impacts that occurred during the pandemic have been tried to a minimum, but there are still some aspects that must be sacrificed in order to save some important points such as some impacts that cannot be avoided namely economic, social, and political impacts.

In making decisions, it must be seen from all sides whether it is from the best possibility to the worst possibility, seeing people from various circles so that they know what is the best thing to do, and in making decisions they must know what problems are being faced so as not to take wrong steps. will cause new problems in the midst of ongoing problems, so that the

policy can run smoothly and in accordance with the initial goal of reducing the spread of COVID-19 as recommended by the central government and in this case the Sindangjaya village government has tried as much as possible.

\section{References}

[1] Efendi, F. K., \& Rofi'ah, E. S. (2017). Pengaruh Pembiasaan Pendidikan Agama Pada Anakterhadap Lingkungan Masyarakat Di Desabungbulang. Thoriqotuna | Jurnal Pendidikan Islam, Volume 2 No 2.

[2] Hadiwardoyo, W. (2020). Kerugian Ekonomi Nasional Akibat Pandemi Covid-19. Baskara : Journal Of Buisness \& Entrepreneurship, Volume 2 No, 2.

[3] Nurkholis. (2020). Dampak Pandemi Novel-Corona Virus Disiase (Covid-19) Terhadap Psikologi Dan Pendidikan Serta Kebijakan Pemerintah. Jurnal Pgsd, Volume 6 No

[4] Ph, L., Suwoso, R. H., Febrianto, T., Kushindarto, D., \& Aziz, F. (2020). Dampak Pandemi Covid-19 Bagi Perekonomian Masyarakat Desa. Indonesian Journal Of Nursing And Health Sciences, 37-48.

[5] Setiawan, A. R. (2020). Lembar Kegiatan Literasi Saintifik Untuk Pembelajaran Jarak Jauh Topik Penyakit Coronavirus 2019 (Covid-19). Edukatif: Jurnal Ilmu Pendidikan, Volume 2. Halaman 28-37.

[6] Susilawati, D., \& Razi, F. (2020). Kebijakan Pemerintah Desa Lowayu Kecamatan Dukun Kabupaten Gresik Dalam Rekonstruksi Ekonomi Pasca Pandemi Covid-19. Uin Sunan Ampel Surabaya, 348 - 359 .

[7] Abdulah, R. (2011). Pelaksanaan Otonomi Luas Dengan Pemilihan Kepala Daerah Secara Langsung . Jakarta: Pt. Raja Grafindo Persada.

[8] Adji, W. (2004). Ekonomi. Bandung: Ganeca Excata.

[9] Dye, T. R. (1984). Thomas R Dye Dalam Understanding Public Policy . Michigan: Prentice-Hall.

[10] Easton, D. (2013). A Systems Analysis Of Political Life. Chicago: University Of Chicago Press.

[11] Gortner, H. F. (1977). Public Administration. California: Wiley.

[12] Gulo, W. (2002). Metodologi Penelitian. Jakarta: Grasindo.

[13] Husaini, U. (2009). Metodologi Penelitian Sosial. Jakarta: Bumi Aksara. 
[14] Miles, M. B., \& Huberman, M. A. (1992). Analisis Data Kualitatif : Buku Sumber Tentang Metode-Metode Baru. Jakarta: U.I Press.

[15] Moleong, R. J. (1989). Metode Penelitian Kualitatif. Jakarta: Remadja Karya.

[16] Sugiyono. (2016). Metode Penelitian Kuantitatif, Kualitatif Dan R\&D. Bandung: Alfabeta.

[17] Sukirno, S. (2013). Pengantar Teori Mikroekonomi. Jakarta: Raja Grafindo. 